\title{
Implementasi Media Audio Visual untuk Meningkatkan Kemampuan Menulis Teks Eksplanasi
}

\author{
Edy Suprianto \\ SDN 004/V Kuala Tungkal, Jl. Syarif Hidayatullah No. 77, Kab. Tanjung Jabung Barat \\ email: edy.s.edu.004@gmail.com
}

\begin{abstract}
This research is a class action research. The research aims to reduce problems in class VI-C SDN 004/V Kuala Tungkal, here is the low ability to write explanatory texts. These problems are reduced by implementing audiovisual media. The results showed an increase in the average score of students in the four aspects measured, namely (1) aspects of the content, the average score of students has increased from 18.77 to 26.30; (2) structural aspects, the average score of students has increased from 14.70 to 17.63; (3) vocabulary aspects, the average student score has increased from 12.33 to 16.30; (4) sentence aspects, the average student score has increased from 13.77 to 16.83; and (4) mechanical aspects, the average student score has increased from 7.23 to 8.33.
\end{abstract}

Keywords: audio-visual media, writing, explanatory text.

\begin{abstract}
Abstrak
Penelitian ini merupakan penelitian tindakan kelas. Penelitian bertujuan untuk mereduksi permasalahan di kelas VI-C SDN 004/V Kuala Tungkal, yakni rendahnya kemampuan dalam menulis teks eksplanasi. Permasalahan tersebut direduksi dengan mengimplementasikan media audiovisual. Hasil penelitian menunjukkan adanya peningkatan rata-rata skor siswa pada keempat aspek yang diukur, yakni (1) aspek isi, rata-rata skor siswa mengalami peningkatan dari 18,77 menjadi 26,30; (2) aspek struktur, rata-rata skor siswa mengalami peningkatan dari 14,70 menjadi 17,63; (3) aspek kosa kata, rata-rata skor siswa mengalami peningkatan dari 12,33 menjadi 16,30 ; (4) aspek kalimat, rata-rata skor siswa mengalami peningkatan dari 13,77 menjadi 16,83 ; dan (4) aspek mekanik, rata-rata skor siswa mengalami peningkatan dari 7,23 menjadi 8,33.
\end{abstract}

Kata Kunci: Media audio visual, menulis, teks eksplanasi.

\section{PENDAHULUAN}

Pendidikan

sedemikian rupa agar warisan budaya, berupa ilmu pengetahuan, keterampilan, dan nilai-nilai dapat dipertahankan bahkan ditingkatkan dari generasi ke genenrasi melalui peranan lembaga pendidikan (Siswoyo, 2007).
Proses pembelajaran yang sejatinya untuk merubah prilaku siswa menjadi lebih baik (Taqwa, Astalini, \& Darmaji, 2015) seharusnya dilakukan dengan menggunakan prinsip berbasis aktivitas. Pembelajaran demikian memenuhi karakteristik seperti interaktif, kolaboratif, kontekstual, 
menyenangkan, inspiratif, menantang dan dapat membangun motivasi siswa. Hal-hal tersebut bertujuan agar dapat membangun kreativitas dan kemandirian siswa sesuai dengan bakat mereka masing-masing.

Salah satu mata pelajaran wajib yang diajarkan dari jenjang pendidikan dasar hingga perguruan tinggi adalah bahasa Indonesia (Andyani, Saddhono, \& Mujyanto, 2017). Bahasa Indonesia memiliki peranan dalam perkembangan pada bermacam bidang, seperti intelektual, sosial, maupun emosional siswa dalam mempelajari bermacam bidang studi lain (Setyawan, 2019). Kompetensi bahasa Indonesia terdiri atas empat aspek yakni menyimak, berbicara, membaca dan menulis. Dari keempat keterampilan tersebut, siswa sering kali kesulitan dalam menulis dan hal tersebut menjadi sorotan bagi praktisi pendidikan khususnya bidang bahasa. Kesulitan tersebut banyak disebabkan oleh kurangnya motivasi dan kemampuan siswa dalam menulis, terutama teks eksplanasi.

Teks eksplanasi merupakan teks yang memuat konten-konten tentang proses yang berhubungan dengan fenomena alam, ilmu budaya, sosial dan topik-tpik lainnya (Priyatni, 2014). Seluruh konten yang termuat dalam sebuah teks eksplanasi memaparkan hal terkait mengapa dan bagaimana suatu pristiwa dapat terjadi. Sejalan dengan hal tersebut, (Kosasih \& Restuti, 2013) menyatakan bahwa teks eksplanasi merupakan teks yang menerangkan atau menjelaskan mengenai proses atau fenomena alam dan sosial. Penting disadari bahwa penguasaan dalam menuliskan teks eksplanasi ini perlu dikuasai oleh siswa. Kendati demikian, siswa justru tidak tertarik dan tidak memiliki motivasi untuk menulis teks eksplanasi. Hal tersebut terjadi di kelas VI C di SDN 004/V Kuala Tungkal.

Berdasarkan hasil observasi pada kegiatan pra siklus yang dilakukan menunjukkan bahwa keterampilan dan motivasi menulis oleh siswa masih tergolong rendah. Hal tersebut diindikasi dari perilaku siswa yang cenderung menunjukkan sikap tidak tertarik saat diminta menulis teks eksplanasi sederhana. Selain itu berdasarkan angket yang disebarkan pada siswa, diperoleh bahwa 13 (43,33\%) siswa mengalam kesulitan pada kemampuan menulis, $9(30,00 \%)$ siswa mengalam kesulitan pada kemampuan berbicara, 5 (16,67\%) siswa mengalam kesulitan pada kemampuan menyimak, dan 3 $(10,00 \%)$ siswa mengalam kesulitan pada kemampuan membaca. Oleh karena itu, penting dilakukan upaya peningkatan kemampuan siswa dalam menulis teks eksplanasi. Dalam artikel ini, pembahasan difokuskan pada upaya untuk meningkatkan kemampuan menulis teks eksplanasi melalui implementasi audia audiovisual..

Media pembelajaran dapat diklasifikasikan menjadi beberapa jenis tergantung dari sudut mana kita melihatnya. Sanjaya (2011) dilihat dari segi sifatnya media dapat dibagi menjadi 3 jenis yaitu media auditif, visual dan audiovisual. Di bawah ini akan diuraikan jenis media berdasarkan sifatnya, yaitu : (1) Media auditif, yaitu media yang dapat didengar suaranya, 
seperti radio dan rekaman suara. (2) Media visual, yaitu media yang dapat dilihat gambarnya, yang termasuk dalam media ini adalah film slide, foto, lukisan dan lain sebagainya yang berbentuk bahan cetak. (3) Media audiovisual, yaitu media yang mengandung unsur suara yang bisa didengar dan unsur gambar yang bisa dilihat, misalnya rekaman video, slide suara dan lain sebagainya.

Media

pembelajaran

Audiovisual adalah suatu media pembelajaran yang dapat didengar suaranya dan dapatdilihat gambarnya secara langsung atau yang sering disebut dengan Video. Media ini sangat baik untuk meransang motivasi dan minat belajar pada siswa dalam pembelajaran menulis teks eksplanasi.

Pembelajaran dengan media audiovisual menjadi pengalaman yang baru bagi siswa, sehingga menimbulkan motivasi dan gairah belajar pada siswa. Pendapat ini didukung oleh Mursini (2012) bahwa media audiovisual adalah media yang mengandung unsur suara dan juga memiliki unsur gambar yang dapat dilihat, seperti rekaman video, film dan sebagainya. Dalam penelitian ini, penulis menggunakan media audiovisual sebagai alat untuk meransang motivasi dan minat siswa terhadap pembelajaran menulis.

Media ini mempunyai

kemampuan yang lebih, karena media ini mengandalkan dua indera sekaligus, yaitu indera pendengaran dan indera penglihatan. Ada beberapa kelebihan media audiovisual menurut Arsyad (2011) Berikut ini akan diuraikan kelebihan media audiovisual (video) antara lain : (1) Memberikan pesan yang dapat diterima secara lebih merata oleh peserta didik. (2) Sangat bagus untuk menerangkan suatu proses. (3) Mengatasi keterbatasan ruang dan waktu. (4) Lebih realistis, dapat diulang-ulang dan dihentikan sesuai dengan kebutuhan. (5) Memberikan kesan yang mendalam, yang dapat mempengaruhi sikap siswa. Media tersebut diharapkan bisa membangkitkan motivasi belajar, memperjelas materi yang disampaikan, dan meningkatkan kemampuan menulis siswa.

Arsyad (2011) mengemukakan bahwa ada empat fungsi media pembelajaran, yaitu: 1) Fungsi atensi dari media visual merupakan fungsi inti dari media pembelajaran, dimana media pembelajaran harus dapat menarik dan mengarahkan perhatian siswa agar dapat berkonsentrasi pada materi pelajaran yang berkaitan. Dengan adanya fungsi ini, diharapkan peserta didik dapat memperoleh dan mengingat isi pelajaran. 2) Fungsi afektif dari media visual dapat dilihat dari tingkat kenikmatan siswa dalam belajar (atau membaca) teks yang bergambar. Gambar atau lambang visual yang ditampilkan diharapkan dapat menggugah emosi dan sikap dari siswa terhadap materi yang disampaikan. 3) Fungsi kognitif, berdasar hasil temuan dari sebuah penelitian mengungkapkan bahwa media visual yang berupa gambar maupun lambang visual dapat memperlancar tujuan untuk memahami dan mengingat informasi yang termuat pada suatu gambar. 4) Fungsi kompensatoris media pembelajaran 
diharapkan dapat berfungsi sebagai alat bantu yang dapat digunakan oleh siswa untuk mempermudah memahami isi teks kemudian mengoganisasikan informasi tersebut agar dapat diingat kembali.

\section{METODE PENELITIAN}

Penelitian ini merupakan penelitian tindakan kelas (PTK) atau class action research yang bertujuan untuk memperbaiki permasalahan yang ada di kelas, yakni adanya kesulitan siswa dalam menuliskan teks eksplanasi. Penelitian tindakan kelas ini penting sebagai paradigma untuk memperbaiki permasalahan yang ada dalam kelas pembelajaran (Damayanti, 2015; Young, Rapp, \& Murphy, 2010) dengan kajian reflektif (Sriyati, 2014). Kajian reflektif sebagai upaya perbaikan permasalahan dilakukan melalui implementasi media audiovisual. Dalam penelitian tindakan kelas ini, guru secara mandiri atau berkolaborasi dengan guru lain dapat melaksanakan penelitian dengan mengamati interaksi siswa dalam proses pembelajara (Hanifah, 2014; Suharsimi \& Suhardjono, 2015).

Penelitian dilakukan di SDN 004/V Kuala Tungkal di kelas VI-C. Subjek penelitian terdiri atas 30 siswa dengan siswa laki-laki sebanyak 16 siswa dan siswa perempuan sebanyak 14 siswa. Penelitian tindakan kelas yang dilakukan ini diadaptasi dari Kemmis, McTaggart, \& Nixon (2013) yang memiliki empat tahapan yakni perencanaan, pelaksanaan, pengamatan, dan refleksi.
Perencanaan

tindakan (planning) dilaksanakan berdasarkan hasil dari identifikasi masalah dan penetapan prioritas masalah yang akan dipecahkan atau direduksi.Berdasarkan kajian yang dilakukan, maka untuk meminimalisir permasalahan yang terjadi di kelas akan diterapkan media audiovisual. Solusi implementasi audiovisual dituangkan dalam Rencana Pelaksanaan Pembelajaran (RPP).

Rencana Pelaksanaan

Pembelajaran (RPP) Bahasa Indonesia disusun sesuai dengan silabus yang telah disusun oleh guru. Selain RPP, disusun pula intrumen penilaian untuk mengukur kemampuan siswa dalam menulis teks eksplanasi.

Pelaksanaan tindakan (acting) berupa penerapan media audiovisual agar dapat meningkatkan motivasi belajar dan hasil keterampilan menulis siswa dalam pembelajaran menulis teks eksplanasi. Setiap tindakan yang dilakukan tersebut selalu diikuti dengan kegiatan pemantauan dan evaluasi serta analisis dan refleksi. Dalam tahap ini peneliti melakukan observasi untuk mengetahui apakah tindakan yang dilakukan telah dapat mengatasi permasalahan yang ada. Selain itu, peneliti juga melakukan observasi untuk mengumpulkan data yang akan diolah untuk mengetahui segala kelemahan yang mungkin muncul. Data yang telah dikumpulkan tersebut diolah untuk menentukan tindakan penelitian berikutnya.

Observasi (observing)dilakukan untuk memonitor tindakan yang terjadi di dalam kelas. Dalam tahap ini, peneliti mengadakan observasi sebagai 
partisipan pasif dimana peneliti berada di dalam lokasi penelitian namun tidak berperan aktif dalam kegiatan yang berlangsung. Setelah itu peneliti mengadakan sharing idea dengan guru yang bersangkutan mengenai hasil pengamatan peneliti. Dalam forum sharing idea tersebut, diungkapkan kelemahan dan kelebihan proses pembelajaran yang berlangsung dengan memfokuskan pada penampilan guru di kelas dan respons siswa terhadap stimulan guru. Setelah data terkumpul, peneliti mengolah data tersebut hingga dapat disajikan pada guru agar dapat dicari solusi untuk berbagai permasalahan yang muncul.

Tahap analisis dan refleksi (reflecting) bertujuan untuk menganalisis hasil evaluasi kemudian dianalisis untuk menentukan langkahlangkah perbaikan apa yang dapat ditempuh, sehingga didapatkan suatu solusi untuk semua permasalahan yang dialami oleh guru dan siswa dalam proses pembelajaran berbicara. Pada tahap ini, peneliti menganalisis atau mengolah data yang telah dikumpulkan, kemudian menyajikannya dalam pertemuan dengan guru yang bersangkutan. Setelah berdiskusi, diambil kesimpulan yang berupa hasil dari pelaksanaan penelitian. Dari hasil penarikan kesimpulan ini dapat diketahui apakah penelitian ini berhasil atau tidak sehingga dapat ditentukan langkah selanjutnya.

Data yang diperoleh dari penelitian ini merupakan data kuantitatif yang diperoleh dari skor penilaian tulisan yang telah dibuat oleh siswa. Teks eksplanasi dinilai berdasarkan 5 aspek yakni, isi, struktur, kosa kata, kalimat, dan mekanik. Skor maksimal ditentukan terlebih dahulu, yakni 30 untuk skor maksimal isi, 20 untuk skor maksimal struktur, 20 untuk skor maksimal kosa kata, 20 untuk skor kalimat dan 10 untuk skor mekanik (Salfera, 2017).

\section{HASIL DAN PEMBAHASAN}

\section{Kegiatan Pembelajaran Siklus I}

Pelaksanaan tindakan dalam siklus I tidak mengalami kendala yang berarti. Pembelajaran pada siklus I dilaksanakan selama 2 jam pelajaran. Pelaksanaan pembelajaran dilakukan dalam beberapa tahapan. Berikut adalah tahapan pelaksanaan pembelajaran yang dilakukan.

Pertama pelaksanaan pembelajaran dimulai dengan membagi siswa menjadi 6 kelompok dengan anggota heterogen. Kondisi heterogen yang dimaksud adalah dari segi gender dan diupayakan dari segi kompetensi masing-masing siswa. Setiap kelompok terdiri atas 5 siswa.

Setelah pembagian kelompok, guru memaparkan penjelasan mengenai definisi, jenis serta struktur teks eksplanasi. Setelah memberikan penjelasan, guru memutar tujuh video yang berbeda. Setiap anggota kelompok diminta untuk memilih salah satu video, dan diminta untuk menjabarkan konten teks eksplanasi yang terkandung dalam video yang dipilih oleh siswa tersebut.

\begin{tabular}{llr}
\multicolumn{2}{c}{ Selama proses } & diskusi \\
berlangsung, guru sebisa & mungkin \\
mengamati & kinerja & siswadalam
\end{tabular}


menyelesaikan tugas. Sebisa mungkin seluruh anggota kelompok diminta untuk terlibat. Siswa juga diarahkan untuk bertukar pikiran agar jiwa sosial mereka terbangun. Selain itu, siswa ataupun kelompok yang mengalami kesulitan diarahkan oleh guru.

Setelah siswa selesai melaksanakan kegiatan diskusi, perwakilan kelompok diminta untuk menyampaikan hasil diskusi yang telah mereka lakukan. Setelah selesai memaparkan hasil diskusi, guru memberikan kesempatan kepada siswa lain untuk memberikan tanggapan terkait paparan hasil diskusi yang diberikan. Hal tersebut bertujuan agar siswa berpartisipasi dalam kegiatan diskusi dan melatih keterampilan sosial siswa (Mustofa \& Tuharto, 2018).

Setelah selesai, guru memberikan tambahan serta feedback terkait hasil diskusi yang telah dilaksanakan. Guru menarik simpulan pelaksanaan pembelajaran yang telah berlangsung. Setelah itu guru memberikan tidak lanjut sebagai bagian asesmen formatif berupa "what next?" agar siswa dapat memperdalam materi pelajaran dan evaluasi individu untuk mengukur keberhasilan siswa pada siklus pertama.

Sebelum menutum menutup pelajaran, guru terlebih dahulu memberikan apresiasi kepada seluruh siswa karena telah belajar dengan baik. Seluruh siswa diminta untuk bertepuk tangan dengan meriah, sehingga mereka merasa dihargai atas keberhasilannya dalam belajar dengan baik.

\section{Kegiatan Pembelajaran Siklus II}

Pelaksanaan tindakan dalam siklus II tidak jauh berbeda dengan pelaksanaan tidakan dalam siklus I. Kegiatan pembelajaran diawali dengan mengulas tugas siswa. Guru membahas pekerjaan siswa yang keliru, menunjukkan kesalahan penulisan yang banyak dilakukan oleh siswa.

Setelah membahas tugas, guru mengulas kembali materi terkait teks eksplanasi. Bagian-bagian esensi diulang agar siswa lebih memhami lebih dalam terkait struktur, ciri-ciri, dan jenis-jenis teks eksplanasi. Pengulangan dilakukan dengan tanya jawab kepada siswa. Siswa nampak antusias dalam menjawab pertanyaan guru. Hal tersebut mengindikasikan bahwa siswa tertarik dengan pembelajaran dan masih mengingat materi pembelajaran yang lalu.

Selesai mengulas materi, guru meminta siswa untuk kembali duduk sesuai kelompok yang telah dibentuk dan membagikan Lembar Kerja Siswa (LKS) kepada siswa. Setelah itu guru memutar video "penyebab kebakaran hutan". Topik tersebut merupakan topik yang menarik karena berkaitan dengan permasalahan yang ada di Jambi. Siswa yang selesai melihat tayangan video diharuskan menemukan struktur teks melalui bimbingan guru.

Setelah selesai menyelesaikan pekerjaan, guru menunjuk beberapa siswa untuk menyampaikan hasil pekerjaannya. Seperti pada siklus I, siswa yang memiliki sanggahan atau saran dipersilahkan untuk disampaikan kepada kelompok penyaji. Setelah selesai melaksanakan kegiatan diskusi 


\section{Suprianto}

guru memberikan tambahan terkait hal- Peningkatan Kemampuan Menulis hal yang masih belum sesuai. Teks Eksplanasi

Kemudian menarik kesimpulan

Peningkatan

kemampuan

pembelajaran bersama-sama dengan menulis teks eksplanasi ditinjau

siswa dan menutup pelajaran. berdasarkan aspek-aspek penting berupa aspek isi, struktur, kosa kata, kalimat dan mekanik. Rata-rata skor siswa untuk tiap aspek pada siklus I dan siklus II ditunjukkan Gambar 1.

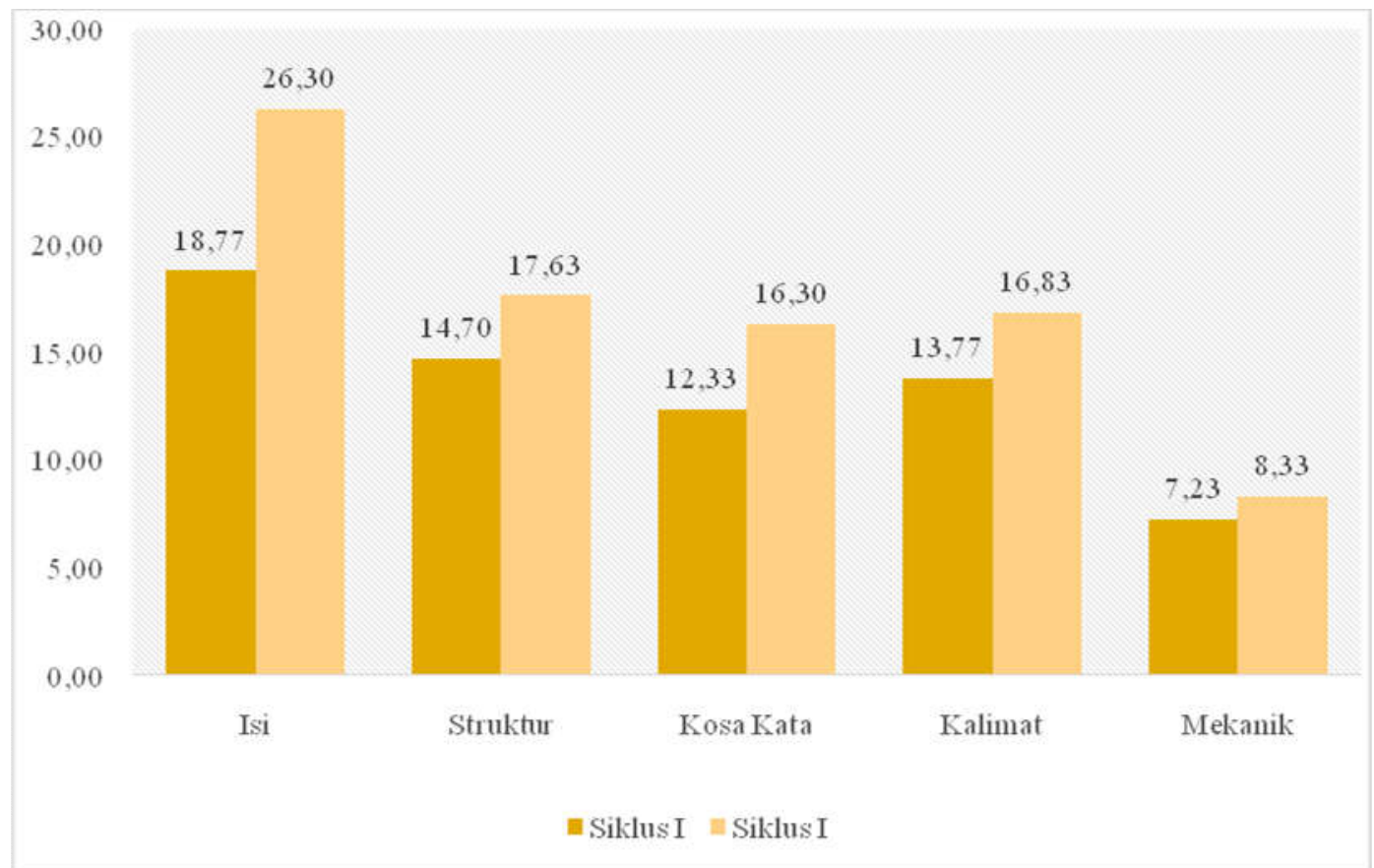

Gambar 1. Rata-Rata Skor Siswa pada Tiap Aspek

Data tersebut menunjukkan bahwa peroleh rata-rata skor tiap aspek yang diperoleh siswa mengalami peningkatan dari siklus I ke siklus II. Pada aspek isi, rata-rata skor siswa mengalami peningkatan dari 18,77 menjadi 26,30 (meningkat sebesar 7,53). Pada aspek struktur, rata-rata skor siswa mengalami peningkatan dari 14,70 menjadi 17,63 (meningkat sebesar 2,93).Pada aspek kosa kata, rata-rata skor siswa mengalami peningkatan dari 12,33 menjadi 16,30 (meningkat sebesar 3,97).Pada aspek kalimat, rata-rata skor siswa mengalami peningkatan dari 13,77 menjadi 16,83 (meningkat sebesar 3,06).Dan terakhir pada aspek mekanik, rata-rata skor siswa mengalami peningkatan dari 7,23 menjadi 8,33 (meningkat sebesar 1,10).

Peningkatan kemampuan siswa dalam menyusun teks eksplanasi terjadi setelah implementasi media audio visual. Dengan menggunakan media 
audio visual siswa lebih menunjukkan minat untuk belajar jika dibandingkan hanya dengan mengimplementasikan pembelajaran konvensional. Hal tersebut sejalan dengan penelitian (Andyani dkk., 2017). Siswa merasa termotivasi dengan media audio visual karena mereka merasa tertarik, merasa ada tantangan (Hemei, 1997).

Penggunaan penggunaan audio visual pula siswa menjadi lebih terstimulus dalam berpikir (Kausar, 2013). Hal tersebut penting, terutama dengan penggunaan media audio visual setidaknya guru telah sedikit memperkenalkan teknologi pada siswa sekolah dasar sejak dini. Karena sejatinya guru memerlukan teknologi dalam proses pembelajaran bahasa (Asadi \& Berimani, 2015).

Penggunaan media audio-visual dapat disesuaikan dengan materi pembelajaran yang akan disampaikan oleh guru kepada siswa. Media audiovisual mampu menyesuaikan kecepatan dan kemampuan belajar siswa. Siswa yang lambat dapat mengulangi materi pembelajaran melalui media audio maupun media visual yang telah diberikan oleh guru, atau mencari sumber lain yang berkaitan dengan materi yang belum dipahami oleh siswa. Sedangkan siswa yang memiliki kemampuan menangkap informasi lebih cepat, siswa dapat melanjutkan belajarnya sesuai dengan kemampuan nya.

Media audio-visual dapat digunakan oleh guru untuk menarik perhatian dari siswa, sehingga materi dapat tersampaikan dan diterima dengan baik. Audio sebagai bahan ajar telah tersedia dalam berbagai ilmu, sehingga dapat dengan mudah dijadikan sebagai penunjang atau alat bantu dalam proses pembelajaran.

Penggunaan media audio visual ini berguna untuk membantu siswa dalam memahami konteks permasalahan, jika dibandingkan dengan permasalahan yang hanya disajikan dalam bentuk teks. Penggunaan media audio visual memiliki beberapa kelebihan diantaranya (1) memberi pengalaman belajar yang sulit dipelajari secara langsung; (2) dapat memberikan pengalaman belajar yang lebih bervariasi sehingga tidak membosankan; dan (3) dapat dijadikan sebagai media belajar mandiri.

Selain meningkatkan kemampuan menulis teks eksplanasi, penggunaan media audio visual dalam pembelajaran Bahasa Indonesia juga digunakan dalam beberapa tujuanberbeda. Misalnya, penelitian Setiawardani (2013) yang menunjukkan bahwa penggunaan media audio visual dapat meningkatkan kemampuan berbicara. Selain itu, media audio visual juga berguna dalam membantu siswa dalam meningkatkan keterampilan menulis karangan deskripsi (Azizah, 2016). Bahkan kemampuan siswa dalam menyimak juga dapat meningkat dengan implementasi media audio visual (Triyadi, 2015).

Penelitian dengan bidikan untuk mengembangkan kemampuan siswa dalam bidang bahasa ini penting untuk terus dikembangkan. Pelajaran apapun yang diminati oleh siswa nantinya, 
bahkan kehidupan seperti apapun kedepannya, kecakapan bahasa adalah hal krusial.

\section{SIMPULAN}

Penggunaan media audio visual berguna dalam meningkatkan kemampuan menulis teks eksplanasi. Hal tersebut diindikasi dari peningkatan skor siswa pada keempat aspek yang diukur, yakni (1) aspek isi, rata-rata skor siswa mengalami peningkatan dari 18,77 menjadi 26,30; (2) aspek struktur, rata-rata skor siswa mengalami peningkatan dari 14,70 menjadi 17,63; (3) aspek kosa kata, rata-rata skor siswa mengalami peningkatan dari 12,33 menjadi 16,30 ; (4) aspek kalimat, rata-rata skor siswa mengalami peningkatan dari 13,77 menjadi 16,83; dan (4) aspek mekanik, rata-rata skor siswa mengalami peningkatan dari 7,23 menjadi 8,33.

Nilai rata-rata kemampuan menulis teks eksplanasi menggunakan media audiovisual lebih baik daripada nilai rata-rata siswa tanpa menggunakan media audiovisual. Hal tersebut dikarenakan media audiovisual selain dapat melibatkan indera pendengaran juga melibatkan indera penglihatan serta melibatkan siswa secara langsung dalam pembelajaran sehingga memberikan gambaran yang konkrit pada siswa. Penggunaan media audio visual diklaim berhasil dalam meningkatkan kemampuan siswa dalam menulis teks eksplanasi dikarenakan siswa lebih merasa termotivasi dan mampu menstimulus siswa untuk lebih berpikir.

\section{DAFTAR RUJUKAN}

Andyani, N., Saddhono, K., \& Mujyanto, Y. (2017). Peningkatan kemampuan menulis teks eksplanasi dengan menggunakan media audiovisual pada siswa sekolah menengah pertama. Basastra, 4(2), 161174.

Arsyad, Azhar. 2011. Media Pembelajaran. Jakarta: Raja Grafindo Persada.

Asadi, F., \& Berimani, S. (2015). The effect of audio-visual materials on Iranian second grade high school students' language achievement. International Journal of Language and Linguistics, 3(2), 69-75.

Azizah, I. N. (2016). Peningkatan keterampilan menulis karangan deskripsi menggunakan media audio visual pada siswa kelas $\mathrm{V}$ SD. BASIC EDUCATION, 5(24), 2-313-2.321.

Damayanti, D. M. (2015). Peningkatan Keterampilan Menulis Teks Eksplanasi Siswa Kelas VII E SMP NEGERI 1 Situbondo dengan Teknik Konsep Kalimat. Nosi, 3(3).

Hanifah, N. (2014). Memahami penelitian tindakan kelas: Teori dan aplikasinya. UPI Press. 
Hemei, J. (1997). Teaching with Video in an English Class. Forum, 35, n2. ERIC.

Kausar, G. (2013). Students' Perspective of the Use of Audio visual Aids in Pakistan. International Proceedings of Economics Development and Research, 68, 11.

Kemmis, S., McTaggart, R., \& Nixon, R. (2013). The action research planner: Doing critical participatory action research. Springer Science \& Business Media.

Kosasih, E., \& Restuti. (2013). Restuti. 2013. Jakarta: Erlangga.

Mursini. 2011. Apresiasi Dan Pembelajaran Sastra Anak-Anak. Bandung: Cipta Pustaka Media Perintis.

Mustofa, A. A., \& Tuharto, M. S. (2018). Efektivitas Penerapan Model Pembelajaran Kooperatif Tipe Numbered Head Together (NHT) dengan Time Tokens ditinjau dari Pemahaman Konsep Matematika dan Keterampilan Sosial Siswa Kelas VII SMP. Jurnal Pendidikan MatematikaS1, 7(2), 48-57.

Priyatni, E. T. (2014). Desain pembelajaran bahasa Indonesia dalam kurikulum 2013. Bumi Aksara.
Sanjaya, Wina H. 2011. Strategi Pembelajaran Berorientasi Standar Proses Pendidikan. Jakarta: Kencana.

Salfera, N. (2017). Meningkatkan Kemampuan Menulis Teks Eksplanasi Dengan Menggunakan Media Gambar Berseri Pada Siswa Kelas VII. Jurnal EDUCATIO: Jurnal Pendidikan Indonesia, 3(2), 32-43.

Setiawardani, W. (2013). Penggunaan Media Audio-Visual Video pada Pembelajaran Bahasa Indonesia untuk Meningkatkan Keterampilan Berbicara. Jurnal Pendidikan, 1(3), 1-9.

Setyawan, C. (2019). Peningkatan Aktivitas dan Hasil Belajar Siswa pada Pembelajaran IPA Materi Gerak Benda Melalui Pendekatan Saintifik. Trapsila: Jurnal Pendidikan Dasar, 1(01), 19-33.

Siswoyo, D. (2007). Ilmu pendidikan. Yogyakarta: UNY Press.

Sriyati, S. (2014). Bagaimana Implementasi Penelitian Tindakan Kelas Dalam Aktifitas Lessons Study. Jurnal Pengajaran MIPA, 19(1), 61-68.

Suharsimi, A., \& Suhardjono, S. (2015). Penelitian Tindakan Kelas Edisi Revisi. Jakarta: PT Bumi Aksara. 
Taqwa, M. R. A., Astalini, \& Darmaji. (2015). Hubungan Gaya Belajar Visual, Auditorial, dan Kinestetik dengan Hasil Belajar Siswa Pada Materi Dinamika Rotasi dan Kesetimbangan Benda Tegar Kelas XI IPA SMA Se-Kota Jambi. 220-227. Purworejo: Universitas Purworejo.

Triyadi, S. (2015). Efektivitas Penggunaan Media Audio-Visual Untuk Meningkatkan
Keterampilan Menyimak Siswa Pada Mata Pelajaran Pendidikan Bahasa Indonesia. JUDIKA (JURNAL PENDIDIKAN UNSIKA), 3(2).

Young, M. R., Rapp, E., \& Murphy, J. W. (2010). Action Research: Enhancing Classroom Practice and Fulfilling Educational Responsibilities. Journal of Instructional Pedagogies, 3. 